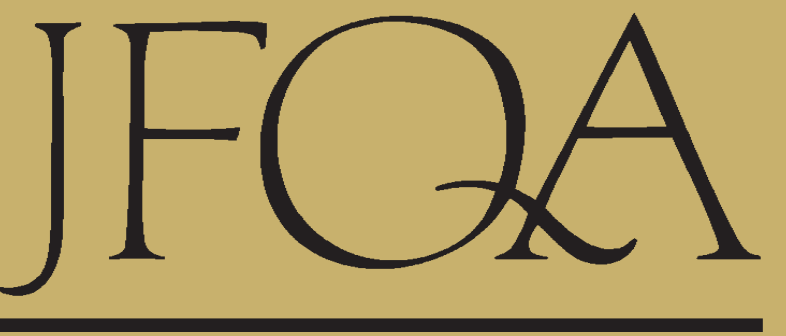

VOL. 48 , NO. 5

OCTOBER 2013

MANAGING EDITORS

Hendrik Bessembinder

Stephen Brown

Jarrad Harford

Paul Malatesta

ADVISORY EDITOR

Mark Grinblatt

ASSOCIATE EDITORS

Warren Bailey

Gurdip Bakshi

Murillo Campello

Mikhail Chernov

Jeffrey Coles

Jennifer Conrad

Jefferson Duarte

Alex Edmans

Wayne Ferson

Jonathan Karpoff

Francis Longstaff

Ronald Masulis

John McConnell

Robert McDonald

Darius Palia

Neil Pearson

George Pennacchi

Jeffrey Pontiff

Jay Ritter

Bryan Routledge

Sergei Sarkissian

Paul Schultz

Chester Spatt

Kumar Venkataraman

Ralph Walkling

Yuhai Xuan

David Yermack

Lu Zhang

Guofu Zhou
Real Assets and Capital Structure

Murillo Campello and Erasmo Giambona

The Joint Dynamics of Equity Market Factors

Peter Christoffersen and Hugues Langlois

Market Development and the Asset Growth Effect: International Evidence

Sheridan Titman, K. C. John Wei, and Feixue Xie

A New Anomaly: The Cross-Sectional Profitability of Technical Analysis

Yufeng Han, Ke Yang, and Guofu Zhou

The Value of (Stock) Liquidity in the M\&A Market Massimo Massa and Moqi $\mathrm{Xu}$

Why Do Hedge Funds Avoid Disclosure? Evidence from Confidential 13F Filings

George O. Aragon, Michael Hertzel, and Zhen Shi

Stock Price Jumps and Cross-Sectional Return Predictability George J. Jiang and Tong Yao

Diversification in Private Equity Funds: On Knowledge Sharing, Risk Aversion, and Limited Attention Mark Humphery-Jenner

Analyst Coverage, Information, and Bubbles Sandro C. Andrade, Jiangze Bian, and Timothy R. Burch

R\&D Spillover Effects and Firm Performance Following $R \& D$ Increases

Sheng-Syan Chen, Yan-Shing Chen, Woan-lih Liang, and Yanzhi Wang

The Impact of Government Intervention in Banks on Corporate Borrowers' Stock Returns

Lars Norden, Peter Roosenboom, and Teng Wang
PUBLISHED BY CAMBRIDGE UNIVERSITY PRESS

FOR THE UNIVERSITY OF WASHINGTON

MICHAEL G. FOSTER SCHOOL OF BUSINESS

IN COOPERATION WITH THE UNIVERSITY OF UTAH

DAVID ECCLES SCHOOL OF BUSINESS

AND THE NEW YORK UNIVERSITY

LEONARD N. STERN SCHOOL OF BUSINESS 
JOURNAL OF FINANCIAL AND QUANTITATIVE ANALYSIS

A PUBLICATION OF THE UNIVERSITY OF WASHINGTON MICHAEL G. FOSTER SCHOOL OF BUSINESS IN COOPERATION WITH THE UNIVERSITY OF UTAH DAVID ECCLES SCHOOL OF BUSINESS AND NEW YORK UNIVERSITY LEONARD N. STERN SCHOOL OF BUSINESS

VOL. 48, NO. 5, OCTOBER 2013

Real Assets and Capital Structure 1333 Murillo Campello and Erasmo Giambona

The Joint Dynamics of Equity Market Factors

Peter Christoffersen and Hugues Langlois

Market Development and the Asset Growth Effect:

International Evidence

Sheridan Titman, K. C. John Wei, and Feixue Xie

A New Anomaly: The Cross-Sectional Profitability of

Technical Analysis

Yufeng Han, Ke Yang, and Guofu Zhou

The Value of (Stock) Liquidity in the M\&A Market 1463

Massimo Massa and Moqi Xu

Why Do Hedge Funds Avoid Disclosure? Evidence from

Confidential 13F Filings 1499

George O. Aragon, Michael Hertzel, and Zhen Shi

Stock Price Jumps and Cross-Sectional Return Predictability 1519

George J. Jiang and Tong Yao

Diversification in Private Equity Funds: On Knowledge Sharing,

Risk Aversion, and Limited Attention

Mark Humphery-Jenner

Analyst Coverage, Information, and Bubbles

Sandro C. Andrade, Jiangze Bian, and Timothy R. Burch

R\&D Spillover Effects and Firm Performance Following

R\&D Increases ......................................... 1607

Sheng-Syan Chen, Yan-Shing Chen, Woan-lih Liang, and Yanzhi Wang

The Impact of Government Intervention in Banks on Corporate

Borrowers' Stock Returns

Lars Norden, Peter Roosenboom, and Teng Wang 
MANAGING EDITORS

Hendrik Bessembinder

Stephen Brown

Jarrad Harford

University of Utah

New York University

Paul Malatesta

University of Washington

\section{ADVISORY EDITOR}

Mark Grinblatt

University of California, Los Angeles

\section{ASSOCIATE EDITORS}

\author{
Warren Bailey \\ Cornell University \\ Gurdip Bakshi \\ University of Maryland \\ Murillo Campello \\ Cornell University
}

Mikhail Chernov

University of California, Los Angeles

Jeffrey Coles

Arizona State University

Jennifer Conrad

University of North Carolina

Jefferson Duarte

Rice University

\section{Alex Edmans}

University of Pennsylvania

Wayne Ferson

University of Southern California

Jonathan Karpoff

University of Washington

Francis Longstaff

University of California, Los Angeles

Ronald Masulis

University of New South Wales

John McConnell

Purdue University

\section{Robert McDonald}

Northwestern University

Darius Palia

Rutgers University

\section{Neil Pearson}

University of Illinois, Urbana-Champaign

\section{George Pennacchi}

University of Illinois, Urbana-Champaign

Jeffrey Pontiff

Boston College

Jay Ritter

University of Florida

Bryan Routledge

Carnegie Mellon University

Sergei Sarkissian

McGill University

Paul Schultz

University of Notre Dame

Chester Spatt

Carnegie-Mellon University

Kumar Venkataraman

Southern Methodist University

Ralph Walkling

Drexel University

Yuhai Xuan

Harvard University

David Yermack

New York University

Lu Zhang

Ohio State University

Guofu Zhou

Washington University in St. Louis

The Journal of Financial and Quantitative Analysis (ISSN 0022-1090), Michael G. Foster School of Business, University of Washington, 370 Mackenzie Hall, UW Box 353200, Seattle, WA 98195-3200, is published bimonthly in February, April, June, August, October, and December by Cambridge University Press, 32 Avenue of the Americas, New York, NY 10013-2473/Cambridge University Press, the Edinburgh Building, Shaftesburg Road, Cambridge CB2 8RU, UK for the University of Washington Michael G. Foster School of Business in cooperation with the David Eccles School of Business at the University of Utah and the Leonard N. Stern School of Business at New York University. Periodicals Postage Paid at New York, NY and additional mailing offices. POSTMASTER: Send address changes to Journal of Financial and Quantitative Analysis, Cambridge University Press, 100 Brook Hill Dr, West Nyack, NY 10994-2133, USA. 
JOURNAL OF FINANCIAL AND QUANTITATIVE ANALYSIS

PHONE: (206) 543-4598

FAX: (206)616-1894

E-MAIL: jfqa@uw.edu

URL: http://www.jfqa.org

University of Washington

Michael G. Foster School of Business

370 Mackenzie Hall UW Box 353200

Seattle, WA 98195-3200 USA

VOL. 48, NO. 5, OCTOBER 2013

\section{PURPOSE AND FOCUS}

The Journal of Financial and Quantitative Analysis (JFQA) publishes theoretical and empirical research in financial economics. Topics include corporate finance, investments, capital and security markets, and quantitative methods of particular relevance to financial researchers. Opinions expressed in the JFQA are those of the authors and do not necessarily reflect those of the University of Washington Foster School of Business. For submissions queries, please write, call, fax, or e-mail the JFQA office. For all other information related to the journal, please contact Cambridge Journals Customer Services: Cambridge University Press, 100 Brook Hill Drive, West Nyack, NY 10994-2133, USA. http://journals.cambridge.org/jfqa

\section{SUBMISSIONS}

www.editorialmanager.com/jfqa

It is JFQA policy to give prompt attention to all submitted manuscripts. Consistent with this policy, honoraria are paid to referees who provide timely reviews. Submit manuscripts online (www.editorialmanager .com/jfqa) with a $\$ 300$ (effective July 1) submission fee and confirmation of a current individual subscription. Checks must be payable to the JFQA in U.S. dollars for deposit in a U.S. bank. VISA, MasterCard, and American Express are accepted. Manuscripts are considered for publication on the understanding that they have not been previously published in whole or in part, and are not being simultaneously considered for publication elsewhere.

\section{SUBSCRIPTIONS}

For individuals or institutions interested in a single journal subscription in 2013, please contact Cambridge Journals Customer Services. In the U.S., Canada, or Mexico, subscription fees are payable in U.S. dollars: journals_subscriptions@cambridge.org. Elsewhere in the world, subscription fees are payable in U.K. pounds sterling: journals@cambridge.org

2013 Annual Subscription Fees

Volume 48: February, April, June, August, October, and December

$\begin{array}{lll}\text { Category } & \text { Access Type } & \text { Price } \\ \text { Organizational } & \text { Online \& Print } & \$ 520 / £ 280 \\ \text { Organizational } & \text { Print only } & \$ 520 / £ 280 \\ \text { Organizational } & \text { Online only } & \$ 395 / £ 215 \\ \text { Individual } & \text { Online \& Print } & \$ 100 / £ 55 \\ \text { Individual } & \text { Print only } & \$ 85 / £ 45 \\ \text { Individual } & \text { Online only } & \$ 70 / £ 40 \\ \text { Student } & \text { Print only } & \$ 25 / £ 17\end{array}$

\section{RIGHTS AND PERMISSIONS}

All rights reserved. No part of this publication may be reproduced, in any form or by any means, electronic, photocopying, or otherwise, without permission in writing from Cambridge University Press. General enquiries from the USA, Mexico, and Canada should be addressed to the New York office of Cambridge University Press http://www.cambridge.org/us/information/rights/contacts/newyork.htm; general enquiries from elsewhere should be addressed to the Cambridge office http://www.cambridge.org/uk/information/rights/contacts/ cambridge.htm; permission enquiries from Australia and New Zealand should be addressed to the Melbourne office http://www.cambridge.org/aus/information/contactsmelbourne.htm; enquiries regarding Spanishlanguage translation rights (only) should be addressed to the Madrid office http://www.cambridge.org/uk/ information/rights/contacts/madrid.htm. Photocopying Information (for users in the USA): Copying for internal or personal use beyond that permitted by Sec. 107 or 108 of the U.S. Copyright Law is authorized for users duly registered with the Copyright Clearance Center (CCC), provided that the appropriate remittance is paid directly to: CCC, 222 Rosewood Drive, Danvers, MA 01923 USA. Specific written permission must be obtained for all other copying; contact the nearest Cambridge University Press office. 